\title{
Measuring Economic and Environmental Performance of Energy Resources in ISIC codes: Evidence from Iran's Industry Sector
}

\author{
Payam Rashidi ${ }^{1}$, Masoud Homayounifar ${ }^{2}$, Taghi Ebrahimi Salari ${ }^{3}$ \& Modjtaba Rouhani ${ }^{4}$ \\ ${ }^{1}$ Ph.D. Student of Economics, Ferdowsi University of Mashhad-Iran \\ ${ }^{2}$ Associated Professors of Economics, Ferdowsi University of Mashhad-Iran \\ ${ }^{3}$ Assistant Professor of Economics, Ferdowsi University of Mashhad-Iran \\ ${ }^{4}$ Assistant Professor of Computer Engineering, Ferdowsi University of Mashhad-Iran \\ Correspondence: Taghi Ebrahimi Salari, Department of Economics, Ferdowsi University of Mashhad, \\ Mashhad-Iran. E-mail: ebrahimi@um.ac.ir, payam.rashidi@mail.um.ac.ir, homayounifar@um.ac.ir, \\ rouhani@um.ac.ir
}

Received: October 16, 2017

Accepted: June 27, 2017

Online Published: November 30, 2017

doi:10.5539/mas.v11n12p109

URL: https://doi.org/10.5539/mas.v11n12p109

\begin{abstract}
Recently, in accordance with global environmental conservation awareness, undesirable outputs of production and social activities (e.g., air pollutants) have harmful social and environmental dimensions especially in developing countries. Therefore, this study discusses how to apply Data Environment Analysis (DEA) for environmental assessment. However, previous DEA research has documented a limited use of DEA on environmental assessment. A unique feature of DEA-based environmental assessment is that it needs to classify outputs into desirable and undesirable outputs. On the other hand, there is a lack of literatures in field of measuring on economic and environmental energy efficiency between ISIC codes. Therefore, this paper measured the energy efficiency of Iran's main ISIC sub sectors using non linear DEA approach. Results indicated that between studied ISIC codes, the codes 15 and 24 have most economic (0.97 and 1.00) and environmental (1.00 and 0.82) efficiency, respectively. Also, in comparison with the other studied ISIC codes, the code 23 is economically and environmentally inefficient (0.28 and 0.32).
\end{abstract}

Keywords: Economic efficiency, environmental efficiency, ISIC codes, DEA

\section{Introduction}

Environmental performance measurement has received increasing attention at different levels due to the global concern about environmental issues and sustainable development. At firm level, the improvement of environmental performance may lead to better financial performance and therefore bring stakeholders huge potential benefits. As such, the measurement of environmental performance has been regarded as the centre of the theoretical framework for business environmental management (Tyteca 1996). At macro level, the measurement of environmental performance measurement helps to make environmental policy analysis and decision making more quantitative, empirically grounded and systematic (Hsuet al. 2014).In accordance with global environmental conservation awareness, undesirable outputs of production and social activities (e.g., air pollutants and hazardous waste) have harmful social and environmental dimensions. Thus, development of technologies with less undesirable outputs is important in every area of production. Data envelopment analysis (DEA) usually indicates that producing more outputs relative to fewer input resources is a criterion of efficiency. In the presence of undesirable outputs, however, one should recognize technologies with more good (desirable) outputs and fewer bad (undesirable) outputs relative to fewer input resources as efficient (Tone and Tsutsui, 2011). A number of modeling techniques have as a result been developed and employed to address complex energy and environmental energy and environmental (E\&E) issues. For example, Jebaraj and Iniyan (2006) reviewed different types of models for energy planning and management. Ang and Zhang (2000) listed a total of 124 studies that applied index decomposition analysis techniques to energy demand and gas emissions analysis. The applications of decision analysis in E\&E studies have been reviewed by Huang et al.(1995) and updated by Zhou et al. (2006).Among the wide spectrum of E\&E modeling techniques, data envelopment analysis (DEA), a relatively new non-parametric approach to efficiency evaluation, has also attracted much attention. Along with 
the wave of deregulation in energy sectors since the late 1980s, DEA has been accepted as a major frontier technique for benchmarking energy sectors in many countries, particularly in the electricity industry (Jamasb and Pollitt, 2001; Abbott, 2005).The rest of this paper is arranged as follows: Section 2 provides a survey of the literature on measuring energy performance. Section 3 represents the method. Section 4 describes our data set, and Section 5 presents the results of measuring energy performance in Iran's main ISIC sub sectors using DEA. Section 6 concludes.

\section{Literature Review}

The previous studies have utilized DEA for environmental assessment because it has considerable research capability for environmental protection. For DEA beginners, Ramanathan (2003) provided an excellent introductory material. The more comprehensive DEA expositions can be found in the recent publication by Cooper et al. (2006). Also, among the previous studies, Seiford and Zhu (2002) developed an approach to incorporating undesirable outputs into BCC-DEA model by using the concept of classification invariance. Färe et al. (2004) proposed an environmental performance index using distance functions. Their index results from a pair of ratios of distance functions. Sueyoshi et al. (2010) and Sueyoshi and Goto (2010) provided a new type of unification to measure the operational, environmental and both-unified efficiency measures of US coal-fired power plants. They have recommended that the US federal and state governments need to expand a legal scope of CAA (Clean Air Act) to the emission control on $\mathrm{CO} 2$ because the gas is considered as a main source of global warming and climate change. Their studies investigated the policy implication by two different data structures and two analytical approaches, using the new unification approach. Tone and Tsutsui (2011) applied an efficiency measure of desirable and undesirable outputs in DEA to U.S. electric utilities. The measure proposed in this paper is a new nonparametric data envelopment analysis (DEA) scheme, the hybrid measure, for determining efficiency in the presence of radial and non radial inputs or outputs. Further extension of the scheme occurred to address non separable desirable and undesirable outputs. Applying the model to measure the overall efficiency of U.S. electric utilities in the presence of both desirable and undesirable outputs indicated that the utilities had improved their overall management and environmental efficiency between 1996 and 2000.Zhou et al (2012) employed the non-radial directional distance function, which is closely linked to the slacks-based DEA models, to assess the energy and carbon performance in electricity generation. Zare and Rostamy (2014) studied the two technologies which is available in the DEA literature for modeling environmental performance under weak disposability assumption of good and bad outputs. Then, they attempted to present a Russell measure that incorporates both desirable and undesirable outputs. To illustrate the use of the proposed method, an empirical application corresponding to 31 administrative regions of China is provided and interpreted. Zhou et al. (2016) in a study provided an introductory text on applications of DEA to environmental performance measurement by describing the formulation of environmental DEA technologies as well as radial and non-radial DEA models for constructing pure environmental efficiency/productivity index. Also, they presented a case study on measuring the environmental performance of OECD countries. Finally, future directions of DEA applications to environmental modeling discussed with reference to several recent developments in this area.

Surveying the previous studies indicates that there is a lack of literatures in field of measuring energy efficiency between ISIC codes with emphasize on economic and environmental efficiency. Therefore, this paper tries to measure the energy efficiency of Iran's main ISIC sub sectors.

\section{Method}

Data Envelopment Analysis (DEA) is a managerial approach to evaluate the operational performance of various organizations in public and private sectors. The DEA is one of very popular management methods (Sueyoshi and Goto, 2011). Also, built upon the earlier work of Farrell (1957), DEA is a well established methodology to evaluate the relative efficiencies of a set of comparable entities by some specific mathematical programming models. These entities, often called decision making units (DMUs), perform the same function by transforming multiple inputs into multiple outputs. A main advantage of DEA is that it does not require any prior assumptions on the underlying functional relationships between inputs and outputs (Seiford and Thrall, 1990). It is therefore a nonparametric approach. In addition, DEA is a data-driven frontier analysis technique that floats a piecewise linear surface to rest on top of the empirical observations (Cooper et al., 2004).

In this study the economic and environmental efficiencies of energy resources (Kerosene, Gas oil, Natural gas, Liquid gas, Gasoline and Crude oil) for each main sub sectors of ISIC include of:

Code 15 - Manufacture of food products and beverages

Code 23- Manufacture of coke, refined petroleum products and nuclear fuel 
Code 24- Manufacture of chemicals and chemical products

Code 26 - Manufacture of other non-metallic mineral products

Code 27 - Manufacture of basic metals

will measured comprehensively while satisfying various complicated equality and inequality constraints. The objectives and constraints of the DEA problem are formulated in this section:

\section{- Objective 1 (Economic Efficiency Maximization)}

In order to maximizing the economic efficiency we reduce all inputs to the largest extent possible by the same output (Mandal and Madheswaran, 2009). The nonlinear DEA model for measuring the input oriented economic efficiency of a DMU with the initial input-output bundle $\left(\mathrm{x}_{0}, \mathrm{y}_{0}\right)$ is represented by model (1):

$$
\mathrm{q}^{*}=\min \mathrm{q} \text {, }
$$

Subject to the following constraints

$$
\begin{aligned}
& \sum_{\mathrm{j}=1}^{\mathrm{n}} x_{i j} I_{\mathrm{j}} \leq q x_{i 0} ;(i=\text { labor }, \text { capital,energy }) \\
& \sum_{\mathrm{j}=1}^{\mathrm{n}} x_{c j} I_{\mathrm{j}}=q x_{c 0} ;(\text { Airpollutan } t s) \\
& \sum_{\mathrm{j}=1}^{\mathrm{n}} y_{j} I_{\mathrm{j}} \geq y_{0} ;(\text { Output }) \\
& \sum_{\mathrm{j}=1}^{\mathrm{n}} I_{\mathrm{j}}=1 ; \\
& I_{j} \geq 0, \quad(j=1,2, \ldots, n)
\end{aligned}
$$

Where $\mathrm{j}$ is indexed as each main sub sectors of ISIC (Code 15, Code 23, Code 24, Code 26, Code 27). Model 1 assumes that the objective of the firms is to reduce all inputs to the largest extent possible by same proportion. Note that inequality (iii) ensures that the resultant output is no lower than what is actually being produced. Inequalities (iv) and (v) indicate that the production set is convex and allows for variable return to scale. An efficient DMU will have $\mathrm{q}^{*}=1$ implying that no equiproportionate reduction in inputs is possible, whereas an inefficient DMU will have $q^{*}<1$.

\section{- Objective 2 (Environmental Efficiency Maximization)}

If we are interested in knowing what is the maximum possible reduction in air pollutants, and define environmental efficiency as the ability of the producer to contract air pollutants to the largest extent possible, that will still allow the firm to produce the observed level of output (or more), without requiring any additional quantities of any other inputs (Mandal and Madheswaran, 2009). The relevant nonlinear DEA model to measure environmental efficiency for a DMU, with the input-output bundle (x0, y0), can be developed as in model (2):

$$
\mathrm{b} *=\min \mathrm{b}
$$

Subject to the following constraints 


$$
\begin{aligned}
& \sum_{\mathrm{j}=1}^{\mathrm{n}} x_{c j} I_{\mathrm{j}}=b x_{c 0} ;(\text { Airpollu } \tan t s) \\
& \sum_{\mathrm{j}=1}^{\mathrm{n}} x_{i j} I_{\mathrm{j}} \leq x_{i 0} ;(\text { i = labor }, \text { capital }, \text { energy }) \\
& \sum_{\mathrm{j}=1}^{\mathrm{n}} y_{j} I_{\mathrm{j}} \geq y_{0} ;(\text { Output }) \\
& \sum_{\mathrm{j}=1}^{\mathrm{n}} I_{\mathrm{j}}=1 ; \\
& I_{j} \geq 0, \quad(j=1,2, \ldots, n)
\end{aligned}
$$

Where $\mathrm{j}$ is indexed as each main sub sectors of ISIC (Code 15, Code 23, Code 24, Code 26, Code 27). The objective here is to reduce only the environmentally detrimental input, total air pollutants $\left(\mathrm{NOx}, \mathrm{SO}_{2}, \mathrm{SO}_{3}, \mathrm{CO}\right.$, $\mathrm{SPM}, \mathrm{CO}_{2}, \mathrm{CH}_{4}$ and $\mathrm{N}_{2} \mathrm{O}$ ) to the maximum extent possible. In doing so, it is not required that other inputs also be reduced. However, inequality (ii) ensures that the other inputs are not increased at the optimum solution. Inequality (iii) ensures that output produced at the optimum level is no lower than what is actually being produced. Inequalities (iv) and (v) indicate that the production set is convex and allows for variable return to scale.

\section{- Constraints}

The constraints of energy resources (Kerosene, Gas oil, Natural gas, Liquid gas, Gasoline and Crude oil) for each main sub sectors of ISIC (Code 15, Code 23, Code 24, Code 26, Code 27) described as below:

$$
\begin{array}{lll}
\sum_{\mathrm{j}=1}^{5} \text { Kerosene }_{\mathrm{j}} \leq \text { Kerosene }_{0} & \left(\mathrm{C}_{1}\right) & \sum_{\mathrm{i}=1}^{6} \mathrm{E}_{\mathrm{i}_{C 15}} \leq \mathrm{E}_{\mathrm{C} 15}^{0} \\
\sum_{\mathrm{j}=1}^{5} \text { Gas oil }_{\mathrm{j}} \leq \text { Gas oil }_{0} & \left(\mathrm{C}_{2}\right) & \sum_{\mathrm{i}=1}^{6} \mathrm{E}_{\mathrm{i} C 23} \leq \mathrm{E}_{\mathrm{C} 23}^{0} \\
\sum_{\mathrm{j}=1}^{5} \text { Natural gas }_{\mathrm{j}} \leq \text { Natural gas }_{0} & \left(\mathrm{C}_{3}\right) & \sum_{\mathrm{i}=1}^{6} \mathrm{E}_{\mathrm{i} C 24} \leq \mathrm{E}_{\mathrm{C} 24}^{0} \\
\sum_{\mathrm{j}=1}^{5} \text { Liquid gas }_{\mathrm{j}} \leq \text { Liquid gas }_{0} & \left(\mathrm{C}_{4}\right) & \sum_{\mathrm{i}=1}^{6} \mathrm{E}_{\mathrm{i} C 26} \leq \mathrm{E}_{\mathrm{C} 26}^{0} \\
\sum_{\mathrm{j}=1}^{5} \text { Gasoline }_{\mathrm{j}} \leq \text { Gasoline }_{0} & \left(\mathrm{C}_{5}\right) & \sum_{\mathrm{i}=1}^{6} \mathrm{E}_{\mathrm{i} C 27} \leq \mathrm{E}_{\mathrm{C} 27}^{0} \\
\sum_{\mathrm{j}=1}^{5} \text { Crude oil }_{\mathrm{j}} \leq \text { Crude oil }_{0} & \left(\mathrm{C}_{6}\right) & \text { All Variables } \geq 0
\end{array}
$$

Where Constraints $C_{1}$ to $C_{6}$ describe that allocation of each energy resource to each considered ISIC code can't 
exceed from its total allocated amount to whole industry sector. Also, Constraints $\mathrm{C}_{7}$ to $\mathrm{C}_{11}$ describe that total allocated amount of each energy resource to each considered ISIC code can't exceed from total allocated amount of energy to that ISIC code.

\section{Data description}

The industry level data of the Iranian main sub sectors of ISIC codes (Code 15, Code 23, Code 24, Code 26, Code 27) for the year 2015 has been extracted from the Iran's annual survey of energy balance sheet and energy census from industrial workstations with more than 10 workers for the relevant year. We conceptualize a single output, three input production function for each five main sub sectors of ISIC codes in Iran. Output is measured by value added of each considered ISIC code. The inputs include (i) capital, (ii) energy (Kerosene, Gas oil, Natural gas, Liquid gas, Gasoline and Crude oil), (iii) labor. Undesirable by-product is measured by total air pollutants ( $\mathrm{NOx}, \mathrm{SO}_{2}, \mathrm{SO}_{3}, \mathrm{CO}, \mathrm{SPM}, \mathrm{CO}_{2}, \mathrm{CH}_{4}$ and $\mathrm{N}_{2} \mathrm{O}$ ) from considered ISIC codes. The capital input is measured as value of changes in capital assets during the studied period. Labor is measured by the total number of production workers. Energy is measured by the expenditure on mentioned fuels. Total amount of value added and air pollutants emission for considered ISIC codes indicated in table 1.

Table1. Total amount of value added and air pollutants emission for Iran's studied ISIC codes

\begin{tabular}{|c|c|c|c|}
\hline $\begin{array}{l}\text { ISIC } \\
\text { codes }\end{array}$ & Description & $\begin{array}{c}\text { Value added } \\
\text { (1000 Billion } \\
\text { RLS) } \\
\end{array}$ & $\begin{array}{c}\text { Total air } \\
\text { pollutants emission } \\
\text { (Million tons) }\end{array}$ \\
\hline 15 & Manufacture of food products and beverages & 143.53 & 8.01 \\
\hline 23 & $\begin{array}{l}\text { Manufacture of coke, refined petroleum products } \\
\text { and nuclear fuel }\end{array}$ & 3.56 & 1.09 \\
\hline 24 & Manufacture of chemicals and chemical products & 355.91 & 33.79 \\
\hline 26 & $\begin{array}{l}\text { Manufacture of other non-metallic mineral } \\
\text { products }\end{array}$ & 114.00 & 29.99 \\
\hline 27 & Manufacture of basic metals & 240.81 & 20.10 \\
\hline
\end{tabular}

\section{Empirical Results}

In this section firstly the amount of various air pollutants emission from considered ISIC codes and their resulted social costs is provided and then the GAMS (General Algebraic Modeling System) software is utilized for the economic and environment efficiency computations. Tables 2 to 8 describe the amount of various air pollutants emission from considered ISIC codes:

Table 2. Total amount of various air pollutants emission for Iran's studied ISIC codes (ton)

\begin{tabular}{|c|c|c|c|c|c|c|c|c|}
\hline Energy $\quad$ Air pollutants & $\mathrm{NO}_{\mathrm{x}}$ & $\mathrm{SO}_{2}$ & $\mathrm{SO}_{3}$ & $\mathrm{CO}$ & SPM & $\mathrm{CO}_{2}$ & $\mathrm{CH}_{4}$ & $\mathrm{~N}_{2} \mathrm{O}$ \\
\hline Kerosene & 4 & 19 & - & 6 & - & 21092 & 1 & 0.2 \\
\hline Gas oil & 12875 & 40428 & 515 & 515 & 3863 & 7255539 & 294 & 59 \\
\hline Natural gas & 131483 & 269 & - & 5222 & 11059 & 83045955 & 1480 & 148 \\
\hline Liquid gas & 34 & 0.1 & - & 22 & - & 51306 & 1 & 0.1 \\
\hline Gasoline & 624 & 69 & - & 16170 & 60 & 109915 & 5 & 1 \\
\hline Crude oil & 28109 & 131930 & 2015 & 10 & 2811 & 9076803 & 352 & 70 \\
\hline
\end{tabular}

Source: research findings

Table 3. Air pollution emission from Kerosene consumption in Iran's studied ISIC codes (ton)

\begin{tabular}{ccccccc}
\hline \multicolumn{1}{c}{$\begin{array}{c}\text { Air pollutant } \\
\text { ISIC code }\end{array}$} & $\mathrm{NO}_{\mathrm{x}}$ & $\mathrm{SO}_{2}$ & $\mathrm{CO}$ & $\mathrm{CO}_{2}$ & $\mathrm{CH}_{4}$ & $\mathrm{~N}_{2} \mathrm{O}$ \\
\hline 15 & 0.166 & 0.790 & 0.249 & 876.898 & 0.042 & 0.008 \\
23 & 0.005 & 0.022 & 0.007 & 24.478 & 0.001 & 0.000 \\
24 & 0.270 & 1.284 & 0.406 & 1425.860 & 0.068 & 0.014 \\
\hline
\end{tabular}


Source: research findings

\begin{tabular}{lllllll}
26 & 1.063 & 5.050 & 1.595 & 5605.527 & 0.266 & 0.053 \\
27 & 0.289 & 1.371 & 0.433 & 1522.333 & 0.072 & 0.014 \\
\hline
\end{tabular}

Table 4. Air pollution emission from Gas oil consumption in Iran's studied ISIC codes (ton)

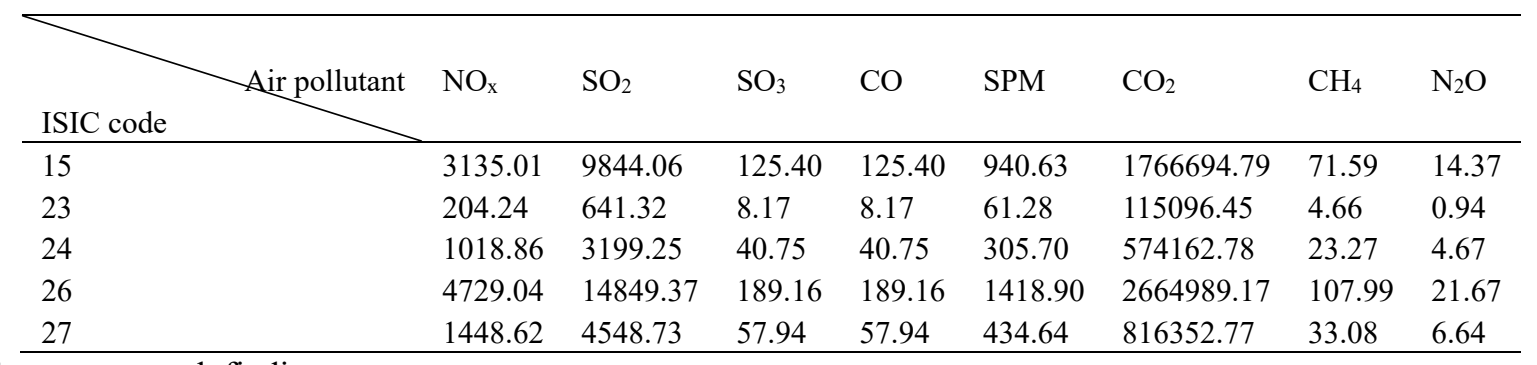

Source: research findings

Table 5. Air pollution emission from Natural gas consumption in Iran's studied ISIC codes (ton)

\begin{tabular}{|c|c|c|c|c|c|c|c|}
\hline ISIC code Air pollutant & $\mathrm{NO}_{\mathrm{x}}$ & $\mathrm{SO}_{2}$ & $\mathrm{CO}$ & SPM & $\mathrm{CO}_{2}$ & $\mathrm{CH}_{4}$ & $\mathrm{~N}_{2} \mathrm{O}$ \\
\hline 15 & 8618.84 & 17.63 & 342.31 & 724.93 & 5443741.81 & 97.02 & 9.70 \\
\hline 23 & 1007.33 & 2.06 & 40.01 & 84.73 & 636240.17 & 11.34 & 1.13 \\
\hline 24 & 52039.85 & 106.47 & 2066.82 & 4377.06 & 32868878.92 & 585.77 & 58.58 \\
\hline 26 & 31760.15 & 64.98 & 1261.39 & 2671.34 & 20060022.74 & 357.50 & 35.75 \\
\hline 27 & 29562.49 & 60.48 & 1174.11 & 2486.49 & 18671960.38 & 332.76 & 33.28 \\
\hline
\end{tabular}

Source: research findings

Table 6. Air pollution emission from Liquid gas consumption in Iran's studied ISIC codes (ton)

\begin{tabular}{|c|c|c|c|c|c|c|}
\hline Air pollutant & & & & & & \\
\hline & $\mathrm{NO}_{\mathrm{x}}$ & $\mathrm{SO}_{2}$ & $\mathrm{CO}$ & $\mathrm{CO}_{2}$ & $\mathrm{CH}_{4}$ & $\mathrm{~N}_{2} \mathrm{O}$ \\
\hline 15 & 3.54 & 0.01 & 2.29 & 5348.87 & 0.10 & 0.01 \\
\hline 23 & 0.21 & 0.00 & 0.13 & 309.91 & 0.01 & 0.00 \\
\hline 24 & 3.74 & 0.01 & 2.42 & 5636.76 & 0.11 & 0.01 \\
\hline 26 & 16.03 & 0.05 & 10.37 & 24195.22 & 0.47 & 0.05 \\
\hline 27 & 3.66 & 0.01 & 2.37 & 5516.12 & 0.11 & 0.01 \\
\hline
\end{tabular}

Source: research findings

Table 7. Air pollution emission from Gasoline consumption in Iran's studied ISIC codes (ton)

\begin{tabular}{llllllll}
\hline $\begin{array}{l}\text { Airpollutant } \\
\text { ISIC code }\end{array}$ & $\mathrm{NO}_{\mathrm{x}}$ & $\mathrm{SO}_{2}$ & $\mathrm{CO}$ & $\mathrm{SPM}$ & $\mathrm{CO}_{2}$ & $\mathrm{CH}_{4}$ & $\mathrm{~N}_{2} \mathrm{O}$ \\
\hline 15 & 121.79 & 13.47 & 3155.94 & 11.71 & 21452.42 & 0.98 & 0.20 \\
23 & 3.43 & 0.38 & 88.85 & 0.33 & 603.99 & 0.03 & 0.01 \\
24 & 118.42 & 13.09 & 3068.65 & 11.39 & 20859.01 & 0.95 & 0.19 \\
26 & 94.35 & 10.43 & 2444.84 & 9.07 & 16618.68 & 0.76 & 0.15 \\
27 & 26.31 & 2.91 & 681.89 & 2.53 & 4635.11 & 0.21 & 0.04 \\
\hline
\end{tabular}

Source: research findings

Table 8. Air pollution emission from Crude oil consumption in Iran's studied ISIC codes (ton)

\begin{tabular}{|c|c|c|c|c|c|c|c|c|}
\hline ISIC code $\quad$ Air pollutant & $\mathrm{NO}_{\mathrm{x}}$ & $\mathrm{SO}_{2}$ & $\mathrm{SO}_{3}$ & $\mathrm{CO}$ & SPM & $\mathrm{CO}_{2}$ & $\mathrm{CH}_{4}$ & $\mathrm{~N}_{2} \mathrm{O}$ \\
\hline 15 & 2251.49 & 10567.41 & 161.40 & 0.80 & 225.16 & 727039.08 & 28.19 & 5.61 \\
\hline
\end{tabular}




\begin{tabular}{lllllllll}
\hline 23 & 1016.18 & 4769.46 & 72.85 & 0.36 & 101.62 & 328139.40 & 12.73 & 2.53 \\
24 & 776.61 & 3645.05 & 55.67 & 0.28 & 77.66 & 250780.21 & 9.73 & 1.93 \\
26 & 21764.86 & 102153.67 & 1560.22 & 7.74 & 2176.56 & 7028187.50 & 272.55 & 54.20 \\
27 & 1697.97 & 7969.43 & 121.72 & 0.60 & 169.80 & 548297.74 & 21.26 & 4.23 \\
\hline
\end{tabular}

Source: research findings

Table 9 describes the resulted social costs of various air pollutants emission for Iran's studied ISIC codes:

Table 9. Resulted social costs of various air pollutants emission for Iran's studied ISIC codes (Million RLS)

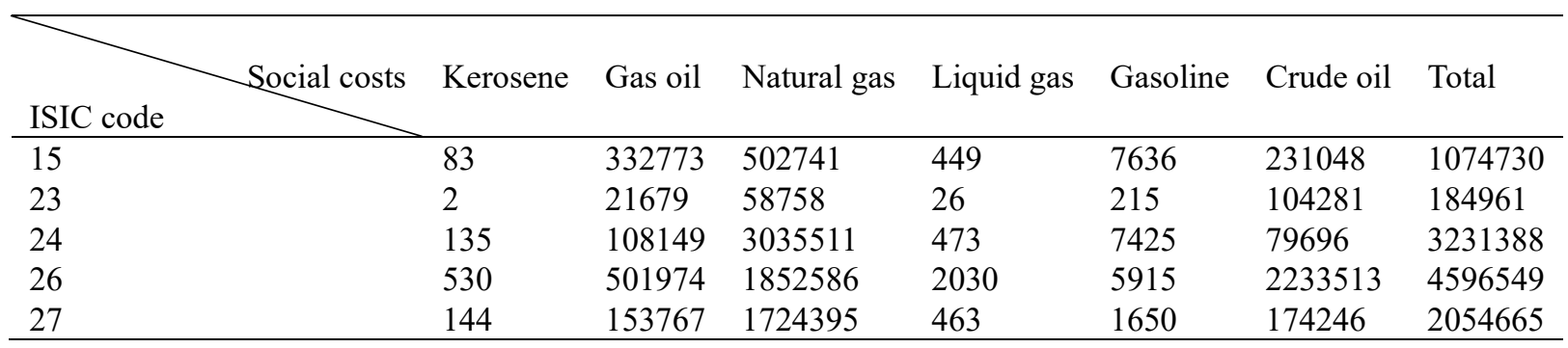

Source: research findings

According to above table between studied ISIC codes, the codes 26 (Manufacture of other non-metallic mineral products) and 23 (Manufacture of coke, refined petroleum products and nuclear fuel) have the most and least resulted social costs of various air pollutants emission. Table 10 indicates the results of calculating economic and environmental efficiency of Iran's considered ISIC codes using nonlinear DEA technique and GAMS software:

Table 10. Economic and environmental efficiency of Iran's studied ISIC codes

\begin{tabular}{lllllll}
\hline \multirow{2}{*}{ ISIC code } & $\begin{array}{l}\text { Value added } \\
\text { (Billion RLS) }\end{array}$ & $\begin{array}{l}\text { Investment } \\
\text { (Billion RLS) }\end{array}$ & $\begin{array}{l}\text { Energy } \\
\text { (Billion RLS) }\end{array}$ & $\begin{array}{l}\text { Labor } \\
\text { (1000Person) }\end{array}$ & $\begin{array}{l}\text { Economic } \\
\text { efficiency }\end{array}$ & $\begin{array}{l}\text { Environmental } \\
\text { efficiency }\end{array}$ \\
\hline 15 & 143533.4 & 18571.8 & 11133.206 & 136.341 & 0.97 & 1.00 \\
23 & 3556.5 & 10124.5 & 318.234 & 26.271 & 0.28 & 0.32 \\
24 & 355911.1 & 27063.7 & 6506.108 & 134.777 & 1.00 & 0.82 \\
26 & 114000.6 & 13041.2 & 9124.834 & 170.007 & 0.66 & 0.40 \\
27 & 240813.3 & 24872.4 & 2550.037 & 216.156 & 0.74 & 0.88 \\
\hline
\end{tabular}

Source: research findings

Results of above table indicate that between studied ISIC codes, the codes 15 (Manufacture of food products and beverages) and 24 (Manufacture of chemicals and chemical products) have complete economic and environmental efficiency, respectively. Also, in comparison with the other studied ISIC codes, the code 23 (Manufacture of coke, refined petroleum products and nuclear fuel) is economically and environmentally inefficient. The schematic economic and environmental energy efficiency of Iran's considered ISIC codes has been illustrated in fig 1: 


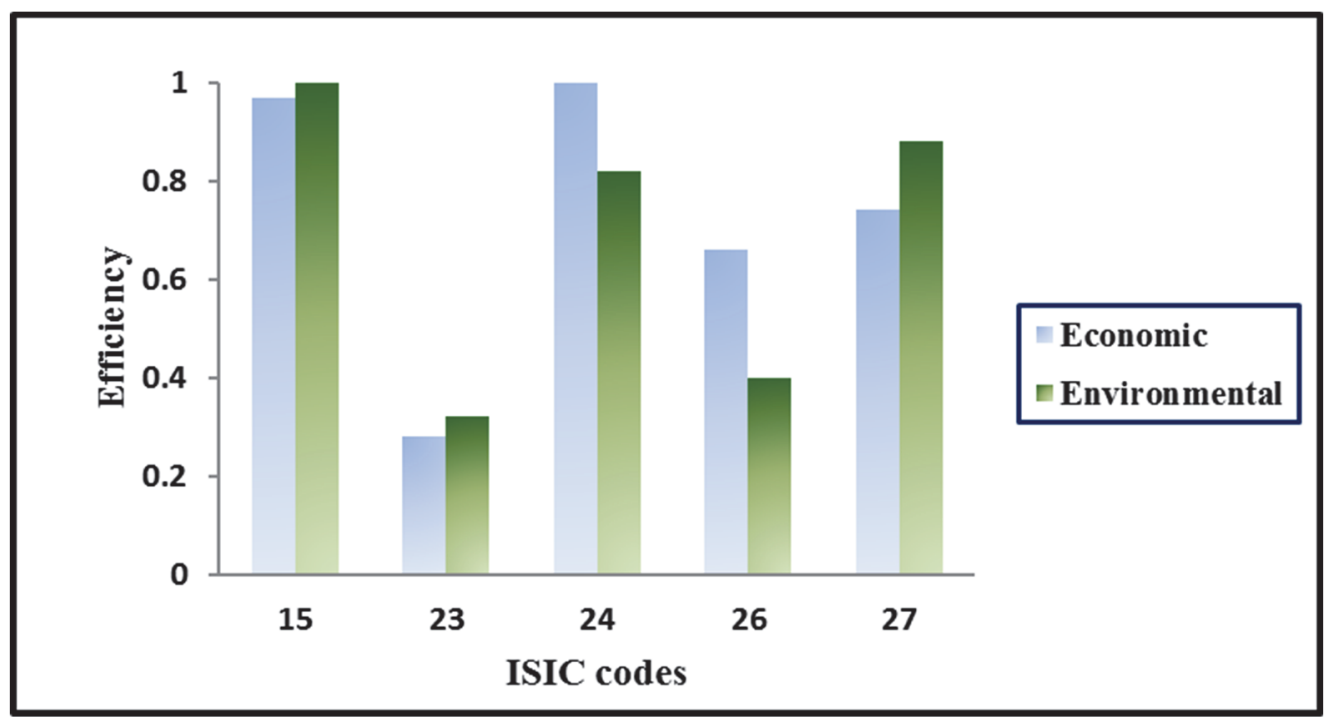

Figure 1. Economic and environmental efficiency of Iran's studied ISIC codes

\section{Conclusion}

Environmental performance measurement has received increasing attention at different levels due to the global concern about environmental issues and sustainable development especially in developing countries. Therefore, in this study apply Data Environment Analysis (DEA) for environmental assessment was discussed. DEA has been long utilized to measure operational performance in private and public sectors. However, previous DEA research has documented a limited use of DEA on environmental assessment. A unique feature of DEA-based environmental assessment is that it needs to classify outputs into desirable (value added) and undesirable (air pollutants) outputs because entities often produce not only desirable outputs but also undesirable outputs as a result of their production activities. On the other hand, there is a lack of literatures in field of measuring on economic and environmental energy efficiency between ISIC codes. Therefore, this paper measured the energy efficiency of Iran's main ISIC sub sectors using non linear DEA approach. Results indicated that between studied ISIC codes, the codes 15 and 24 have most economic (0.97 and 1.00) and environmental (1.00 and 0.82) efficiency, respectively. Also, in comparison with the other studied ISIC codes, the code 23 is economically and environmentally inefficient $(0.28$ and 0.32$)$.

\section{References}

Abbott, M. (2005). Determining levels of productivity and efficiency in the electricity industry. The Electricity Journal, 18(9), 62-72.

Ang, B. W., \& Zhang, F. Q. (2000), A survey of index decomposition analysis in energy and environmental studies. Energy, 25, 1149-1176.

Cooper, W. W., Seiford, L. M., \& Tone, T. (2006). Introduction to Data Envelopment Analysis and Its Uses: With DEA-Solver Software and References. Springer, New York.

Cooper, W. W., Seiford, L. M., \& Zhu, J. (2004). Data envelopment analysis: History, models and interpretations. In: Cooper, L.M., Seiford, L.M., Zhu, J. (Eds.), Handbook on Data Envelopment Analysis. Kluwer Academic Publishers, Boston, pp: 1-39.

Färe, R., Grosskopf, S., \& Hernandez-Sancho, F. (2004). Environmental performance: An index number approach. Resource and Energy Economics, 26(4), 343-352.

Farrell, M. J. (1957), The measurement of productive efficiency. Journal of the Royal Statistical Society, Series A (General), 120, 253-281.

Hsu, A., Emerson, J., Levy, M., de Sherbinin, A., Johnson, L., Malik, O., Schwartz, J., \& Jaiteh, M. (2014). The 2014 environmental performance index. New Haven, CT: Yale Center for Environmental Law \& Policy. Retrieved from www.epi.yale.edu.

Huang, J. P., Poh, K. L., \& Ang, B. W. (1995). Decision analysis in energy and environmental modeling. Energy, 
$20,843-855$.

Jamasb, T., Nillesen, P., \& Pollitt, M. (2004). Strategic behavior under regulatory benchmarking. Energy Economics, 26, 825-843.

Jebaraj, S., \& Iniyan, S. (2006). A review of energy models. Renewable and Sustainable Energy Reviews, 10, 281-311.

Mandal, S. K., \& Madheswaran, S. (2009). Environmental Efficiency of the Indian Cement Industry: An Interstate Analysis, working paper, The Institute for Social and Economic Change, Bangalore.

Ramanathan, R. (2003). An Introduction to Data Envelopment Analysis: A Tool for Performance Measurement. Sage Publications, New Delhi.

Seiford, L. M., \& Thrall, R. M. (1990). Recent developments in DEA: The mathematical programming approach to frontier analysis. Journal of Econometrics, 46, 7-38.

Seiford, L. M., \& Zhu, J. (2002). Modeling undesirable factors in efficiency evaluation. European Journal of Operational Research, 142, 16-20.

Sueyoshi, T., \& Goto, M. (2010). Should the US Clean Air Act include CO2 emission control?: Examination by data envelopment analysis. Energy Policy, 38, 5902-5911.

Sueyoshi, T., Goto, M., Ueno, T. (2010). Performance analysis of US coal-fired power plants by measuring three DEA efficiencies. Energy Policy, 38, 1675-1688.

Tone, K., \& Tsutsui, M. (2011). Applying an Efficiency Measure of Desirable and Undesirable Outputs in DEA to U.S. Electric Utilities. Journal of CENTRUM Cathedra, 4(2), 236-249.

Tyteca, D. (1996). On the measurement of the environmental performance of firms-A literature review and a productive efficiency perspective. Journal of Environmental Management, 46, 281-308.

ZareHaghighi, H., \& Rostamy Malkhalifeh, M. (2014). Russell Measure for Modeling Environmental Performance. Int. J. Data Envelopment Analysis, 2(1), 323-332.

Zhou, P., Ang, B. W., \& Poh, K. L. (2006). Decision analysis in energy and environmental modeling: An update. Energy 31, 2604-2622.

Zhou, P., Ang, B. W., \& Wang, H. (2012). Energy and CO2 emission performance in electricity generation: A non-radial directional distance function approach. European Journal of Operational Research, 221, 625635.

Zhou, P., Poh, K. L., \& Ang, B. W. (2016). Data Envelopment Analysis for Measuring Environmental Performance, International Series in Operations Research \& Management Science 239. https://doi.org/10.1007/978-1-4899-7705-2_2

\section{Copyrights}

Copyright for this article is retained by the author(s), with first publication rights granted to the journal.

This is an open-access article distributed under the terms and conditions of the Creative Commons Attribution license (http://creativecommons.org/licenses/by/4.0/). 